\title{
Seagrass structural complexity and landscape configuration as determinants of tropical fish assemblage composition
}

\author{
Martin Gullström ${ }^{1, *}$, Maria Bodin ${ }^{2}$, Per G. Nilsson ${ }^{3}$, Marcus C. Öhman ${ }^{1}$ \\ ${ }^{1}$ Department of Zoology, Stockholm University, 10691 Stockholm, Sweden \\ ${ }^{2}$ Department of Marine Ecology, Göteborg University, Box 461, 40530 Göteborg, Sweden \\ ${ }^{3}$ Tjärnö Marine Biological Laboratory, Department of Marine Ecology, Göteborg University, 45296 Strömstad, Sweden
}

\begin{abstract}
Seagrass meadows are regularly used by fish as resident, transient, or nursery habitat. However, there is a long-standing debate on how spatial variability of seagrass fish assemblages is determined. We examined the influence of seagrass structural complexity, physical water conditions, and proximity of neighboring shallow-water habitats on tropical fish assemblage composition in a shallow seagrass-dominated embayment at Zanzibar Island in the western Indian Ocean. Sampling of fish assemblages was carried out in seagrass meadows dominated by Enhalus acoroides or Thalassia hemprichii (3 localities each), 1 mixed meadow, and 1 unvegetated area. Overall, the density and biomass of fish were dominated by juvenile and subadult herbivores, either stationary seagrass residents or fish associated with coral reef and seagrass habitats. In terms of number of fish species, the majority were either carnivorous or omnivorous, and mainly coral-seagrass-associated. Multiple regression analysis indicated that canopy height was the foremost predictor for density, biomass, and species richness of juvenile fish, whereas adult and subadult fish densities were predicted by water depth. Moreover, distance-based correlation analyses revealed that fish assemblage structure was significantly correlated with the distance to neighboring mangrove and coral-reef habitats, shoot density, and (although weaker) canopy height. Based on these findings, attributes of seagrass structure and the location of a seagrass habitat within the seascape context appear to be important determinants of spatial patterns and variability of seagrass fish assemblages. This kind of information is important for spatial coastal management and for the selection of marine protected areas.
\end{abstract}

KEY WORDS: Seagrass fish · Spatial variability $\cdot$ Community patterns $\cdot$ Life stage $\cdot$ Habitat complexity $\cdot$ Seascape configuration · Tropical embayment

Resale or republication not permitted without written consent of the publisher

\section{INTRODUCTION}

Understanding which major factors determine spatial patterns of organisms is a fundamental goal in community ecology (Morin 1999), and also a key component in providing valuable information for successful conservation of natural environments (Benedetti-Cecchi et al. 2003). For seagrass meadows, acknowledged as one of the most productive and diverse ecosystems on earth (Hemminga \& Duarte 2000), there are opposing theories about processes on various scales driving spatial community-level patterns.
Seagrass ecosystems provide keystone environments for numerous marine organisms migrating among shallow-water habitats (Connolly \& Hindell 2006), and their significance as nursery ground for fish has drawn specific attention (Jackson et al. 2001). Although the nursery concept is debated (Beck et al. 2001, Heck et al. 2003), it is widely established that juvenile fish regularly inhabit seagrass meadows to take advantage of the rich food supply (Edgar \& Shaw 1995) and escape predators before migrating to adult habitats (Orth et al. 1984). However, though several studies have attempted to explain seagrass fish community patterns by factors 
using a single scaling approach (e.g. Bell \& Westoby 1986a, Baelde 1990, Hyndes et al. 2003, Jelbart et al. 2007), little is known about the relative importance of a broad-scale spectrum of processes (but see e.g. Hovel et al. 2002).

With a few contradictions (e.g. Heck \& Thoman 1984), it is widely recognized that seagrass habitats support a more abundant and diverse fish fauna than adjacent unvegetated areas (see reviews by Pollard 1984, Heck et al. 2003). A low degree of similarity in the distribution patterns of fish has also been shown in neighboring seagrass meadows of different species composition (Blaber et al. 1992, Gullström et al. 2002), plant morphology, and meadow architecture (Hyndes et al. 2003). One explanatory factor that has received much attention is seagrass structural complexity, which has been suggested as an important factor regulating fish assemblages (e.g. Adams 1976, Heck \& Orth 1980, Bell \& Westoby 1986a, Connolly 1994a, Hyndes et al. 2003), even though few have confirmed strong positive effects (but see e.g. Heck \& Orth 1980, Bell \& Westoby 1986a). Heck \& Orth (1980) suggested that a high seagrass structural complexity diminishes predator foraging efficiency, thereby positively affecting survival of fish. However, Bell \& Westoby (1986a), using manipulative field experiments, proposed that a higher number of juvenile fish in denser seagrass meadows was mainly due to habitat preference, rather than reduced predation. Moreover, the selection of a specific seagrass area might also be based on prey availability (Connolly 1994a,b). Nevertheless, habitat selection seems to be a trade-off between food availability and predation risk, and the choice of habitat may shift with increasing fish body size and the potential increase in size refuge from predation (Dahlgren \& Eggleston 2000). One such example of habitat shift is that seagrass meadows are often used as a nursery environment by ontogenetically migrating reef-fish species (e.g. Nagelkerken et al. 2001). Contrary to early local-scale theory that seagrass structural complexity and fish community composition are related (Heck \& Orth 1980, Bell \& Westoby 1986a), seagrass shoot density (used as a structural complexity measure) has been shown to be of little importance for variation in fish density (Bell \& Westoby 1986b, Worthington et al. 1992) and settling of fish larvae (Bell et al. 1987) over large (km) spatial scales.

Since many fish species are highly mobile and shift habitat during their lifetime, the distance among neighboring shallow-water habitats may also influence the abundance and composition of fish communities (Parrish 1989, Mumby et al. 2004). Such relationships based on habitat connectivity have rarely been examined for seagrass-associated fish (but see e.g. Baelde 1990, Jelbart et al. 2007). In general, the degree of connectivity among coastal habitats has been suggested to depend on prevailing migration and recruitment patterns (Gillanders et al. 2003) and a combination of interactive and non-independent factors such as the degree of isolation, size, and shape of habitats (Tanner 2003, Russell et al. 2005). Migration patterns are provided either via short-term diel and tidal movements (e.g. Robblee \& Zieman 1984, Dorenbosch et al. 2004a) or by long-term migration over large distances (McClanahan \& Mangi 2000) as responses of episodic need for better foraging and sheltering success (Weinstein \& Heck 1979), whereas recruitment principally depends on species-specific dispersal patterns (Edgar 1992). Both migration and recruitment might rely on local physical water properties (water temperature, salinity, depth, etc.) and other more general hydrodynamic settings (bathymetry, currents, etc.), factors which may also influence distribution patterns of seagrass fish assemblages (Livingston 1984, Sogard et al. 1987). These abiotic processes can promote development and occurrence of seagrass meadows (Fonseca \& Kenworthy 1987), which themselves function as feedback systems reducing current flow and wave energy via their structural component (Gambi et al. 1990), thereby changing prerequisites for recruitment and structuring of fish communities.

Few studies have focused on various processes at multiple spatial scales and their relationships with assemblage composition of seagrass fish fauna. Hence, the main objective of the present study was to examine the relative importance of fine-scale within-meadow characteristics and landscape configuration in shaping the composition of seagrass fish assemblages in a tropical marine embayment. A further purpose was to investigate whether the importance of structuring factors differed among different size classes (life stages) of fish. Through multiple linear regression and distancebased correlation analyses, we tested the explicit hypotheses that density, biomass, species richness, and assemblage structure of fish were organized by (1) seagrass structural complexity (shoot density, shoot biomass, and canopy height), (2) local physical water conditions (temperature, salinity, and water depth), and/or (3) the distance from seagrass meadows to neighboring mangrove and coral-reef habitats.

\section{MATERIALS AND METHODS}

Study area. The present survey was conducted in Chwaka Bay $\left(6^{\circ} 6-13^{\prime} \mathrm{S}, 39^{\circ} 24-31^{\prime} \mathrm{E}\right)$, situated on the east coast of Zanzibar Island (Unguja), Tanzania (Fig. 1). Chwaka Bay is a relatively shallow (mean depth $3.2 \mathrm{~m}$ ), semi-enclosed, tidal embayment of $\sim 50 \mathrm{~km}^{2}$. The bay is influenced by a strong and asymmetric semidiurnal tidal regime where the ebb cur- 
rents are stronger than the flood currents, and the average daily tide ranges from $0.9 \mathrm{~m}$ during neap tide to $3.2 \mathrm{~m}$ during spring tide (Cederlöf et al. 1995). In general, the morphology of the bay is characterized by an extensive network of channels with water currents predominantly forced in a north-south direction and a sea bottom that mainly consists of biogenic deposits and eroded material derived from fossil limestone terraces (Tobisson et al. 1998). The channel system of Chwaka Bay is surrounded by intertidal and subtidal seagrass meadows of either mixed or monospecific nature, often interspersed with a substantial amount of seaweed vegetation (Gullström et al. 2006). Eleven seagrass species are present, of which Cymodocea rotundata, C. serrulata, Enhalus acoroides, Thalassia hemprichii, and Thalassodendron ciliatum are dominant. Intertidal areas found in the central, western, and southeastern parts of the bay are composed principally of T. hemprichii, Cymodocea spp., and the calcareous algae Halimeda spp., whereas subtidal central parts are dominated by E. acoroides or T. ciliatum. Mixed plant assemblages (seagrass and macroalgae) are commonly scattered within the channel system. The southern bay shoreline is fringed by an extensive mangrove forest ( 3000 ha) with 7 mangrove species identified and several tidally influenced creeks characterized by mangrove prop roots (Lugendo et al. 2005). In the vicinity of the mangrove forest are widespread sand flats, partly covered by T. hemprichii and Cymodocea spp. At the entrance of the bay, close to Michamvi Peninsula (Fig. 1), is a large intertidal sand flat covered to some extent by a mixed assemblage of seagrass and macroalgae. The bay entrance is bordered by a heterogeneous coral reef, mainly characterized by patch reefs and fragmented reef boulders of various sizes.

The field survey was carried out from November 2002 to January 2003, which partly corresponds with 1 out of 2 rainy seasons in the area (McClanahan 1988). All field sampling was conducted in meadows dominated by Enhalus acoroides (E1, E2, and E3) or Thalassia hemprichii (T1, T2, and T3), a mixed meadow of E. acoroides, T. hemprichii, Thalassodendron ciliatum, and bare sediment (M), and an adjacent unvegetated sediment bank (U) (Fig. 1). All sites dominated by $E$. acoroides or $T$. hemprichii were chosen in order to represent homogeneous seagrass meadows. Due to the lack of seagrass on site $U$, this site was excluded from the statistical correlation and regression analyses.

Fish sampling and data processing. Fish assemblages were sampled during daytime at high tide $( \pm 2 \mathrm{~h})$ over 4 consecutive spring tide periods (except for $\mathrm{U}$, which was only sampled 3 times due to logistical weather problems) using a beam trawl with an opening of $2 \mathrm{~m}$ in width and $0.6 \mathrm{~m}$ in height. The trawl had an attached net with an unstretched mesh size of $6 \mathrm{~mm}$ and a cod end of $1 \mathrm{~mm}$. On each sampling occasion,
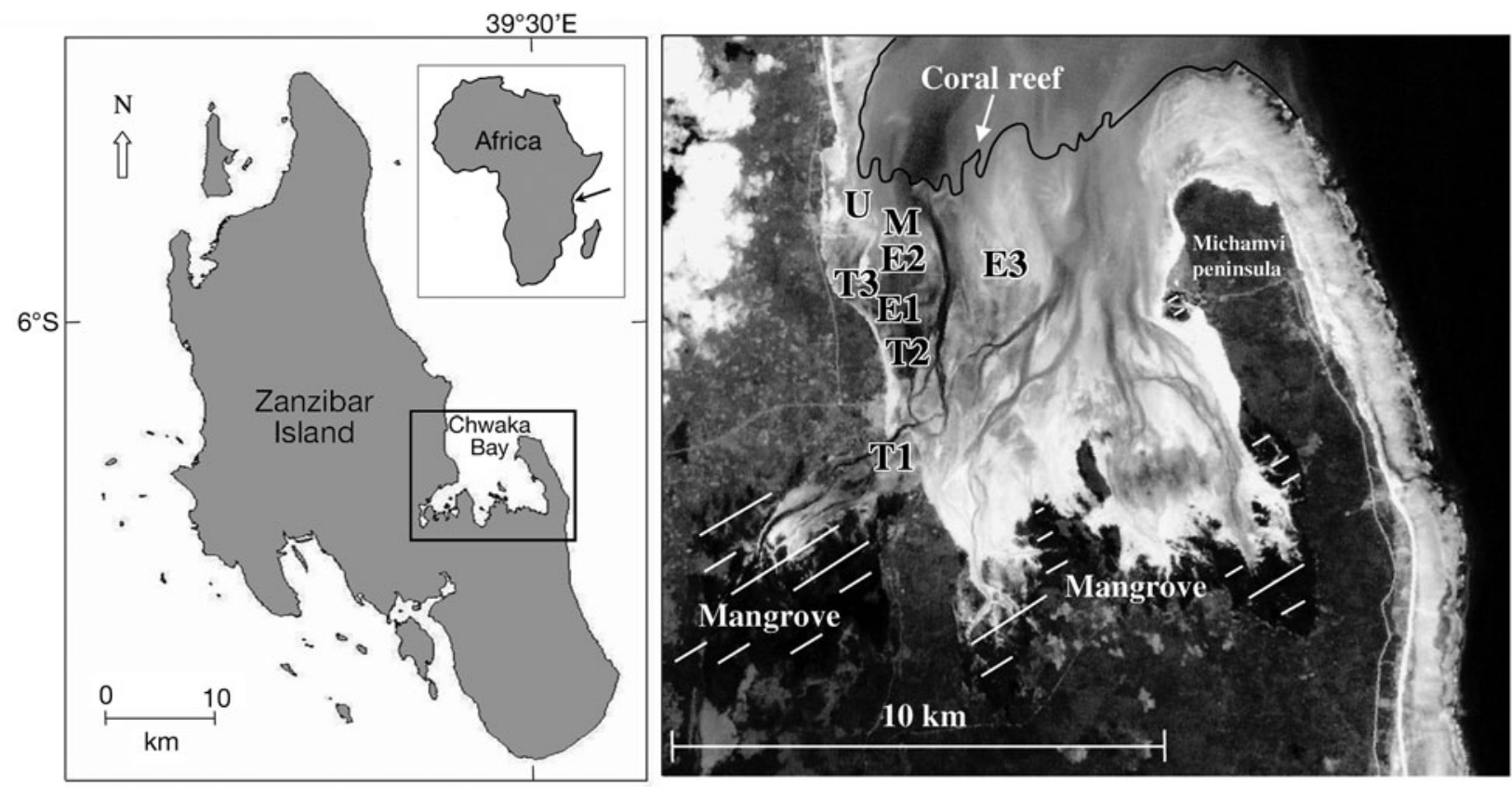

Fig. 1. Location of study sites in the seagrass-dominated Chwaka Bay, Zanzibar Island (Unguja), Tanzania (left panel), marked on a Landsat ETM image from 30 January 2003 (right panel). The sampling areas included meadows dominated by Enhalus acoroides (E1, E2, and E3), meadows dominated by Thalassia hemprichii (T1, T2, and T3), a mixed meadow of E. acoroides, T. hemprichii, Thalassodendron ciliatum, bare sediment (M), and an unvegetated area (U). Approximate positions of mangrove forest (white crosswise-stripped areas) and interior part of the coral reef (black continuous line) are shown 
6 semi-randomly selected $200 \mathrm{~m}$ transect hauls (replicates) were conducted at each site $(200 \times 150 \mathrm{~m}$ in size). Fish caught were sorted, frozen, and stored on ice for further analysis. In the laboratory, all individuals were counted, measured for total length (TL) to the nearest $\mathrm{mm}$, and wet-weighed to the nearest $0.01 \mathrm{~g}$. All fish were identified to the lowest taxonomic level possible following Smith \& Heemstra (1991). One species, the eeltail catfish Plotosus lineatus, was not included in any statistical or comparative analyses due to its extreme shoaling behavior and highly sporadic occurrence.

Life stages were divided into 3 size classes based on species' maximum lengths (from Froese \& Pauly 2005) following Nagelkerken \& van der Velde (2002). Hence, juveniles (the small size class) represent individuals of $<1 / 3$ maximum length, subadults (the medium size class) $1 / 3$ to $2 / 3$ of the maximum length, and adults (the large size class) $>2 / 3$ maximum length. According to information from Froese \& Pauly 2005), fish species were classified into generalists, mangrove-seagrassassociated, coral-seagrass-associated, seagrass residents, and species associated with unvegetated sand or mud flats. 'Generalists' refers to fish species that use multiple habitats (i.e. mangroves, seagrass meadows, and coral reefs), whereas the terms 'mangroveseagrass-associated' and 'coral-seagrass-associated', respectively, are applied to species that mainly proliferate in 2 specific habitats throughout their lifetime.

Seagrass habitat characterization. Three parameters were used to assess seagrass structural complexity: shoot density, shoot (above-ground) biomass, and canopy height. The measurement of structural components was conducted at 20 randomly selected $100 \mathrm{~m}^{2}$ spots within the $200 \times 150 \mathrm{~m}$ grid at each seagrass locality (i.e. the same as used for fish sampling). At each of the 20 spots, plant shoots were collected, and density was estimated in 2 randomly placed $0.25 \times$ $0.25 \mathrm{~m}$ frames. The seagrass was subsequently analyzed in the laboratory for shoot biomass after being dried at $80^{\circ} \mathrm{C}$ for $72 \mathrm{~h}$. Canopy height was determined by measuring 16 seagrass plants in each of 8 randomly placed $0.5 \times 0.5 \mathrm{~m}$ frames (within each of the 20 selected spots mentioned above), following methodological suggestions by Duarte \& Kirkman (2001).

Physical water conditions. Water temperature, salinity, and depth were recorded near the top of the seagrass canopy at the start and end positions of each fish sampling transect. The mean of the 2 measurements for each parameter at all transects was subsequently used as predictor data in correlation and regression analyses (for details see 'Statistical analyses').

Proximity of neighboring habitats. In order to relate density, biomass, species richness, and assemblage structure of fish to seagrass site position, the proximity from the central part of each seagrass sampling locality (i.e. not including $U$ ) to the nearest part of neighboring mangrove and coral-reef habitats, respectively, was estimated using a Landsat satellite image. Calculated distances were then used as predictor variables in regression and correlation analyses.

Statistical analyses. Data of seagrass structural complexity measurements (i.e. shoot density, shoot biomass, and canopy height) were analyzed using nested ANOVAs with Meadow type (2 levels) as a fixed factor and Site (3 levels) as a random factor nested within Meadow type. Variability in density (total assemblages, juveniles, subadults, and adults), biomass (total assemblages), and species richness of fish were analyzed using mixed-model ANOVAs with Meadow type (2 levels, fixed) and Occasion (4 levels, random) treated as orthogonal factors, and Site (3 levels) as a random factor nested within Meadow type. Prior to all ANOVA analyses, the assumption of homogeneity of variances was checked by Levene's test, and the data was $\log _{10}(\mathrm{x}+1)$-transformed when necessary. When the data remained heteroscedastic despite transformations, hypotheses were rejected at alpha levels lower than the p-values of the Levene's test (Underwood 1981). Pearson's chi-squared test of independence was applied to test whether the proportion of individuals in the 3 size classes (juveniles, subadults, and adults) differed among localities (and subsequently to compare each of them to a standard normal distribution).

Stepwise multiple linear regression analysis was used to explore the relative importance of various continuous predictor variables, i.e. seagrass structural complexity (shoot density, shoot biomass, and canopy height), local physical water conditions (temperature, salinity, and water depth), and the distance from seagrass meadows to neighboring habitats (i.e. mangrove and coral reef) on fish density (total assemblages, juveniles, subadults, and adults), biomass (total assemblages), and species richness. The probability criteria to enter or remove predictor variables were specified to 0.05 and 0.1 , respectively. Prior to the analysis, we checked the predictor variables for colinearity.

In order to separate the effect of seagrass structure from the effect of seagrass species on fish density, a linear analysis of covariance (ANCOVA) was applied. We used seagrass species as a categorical factor, canopy height as a continuous predictor (covariate) variable, and fish density as the dependent variable. Canopy height was chosen as the covariate variable because it showed the highest variability among the different seagrass structural complexity variables.

Spatial patterns of fish assemblage structure (derived from species composition and relative abundances) were examined for total density and total biomass with a non-parametric multivariate technique 
using the PRIMER Software package (Clarke \& Warwick 1994). Two-way crossed analysis of similarities (ANOSIM) was used to test for differences in fish assemblage structure among localities and among size classes. Patterns of similarities were visualized using non-parametric multidimensional scaling (NMDS) based on the Bray-Curtis similarities measure (a wellsuited similarities index since it does not require exclusion of rare species), calculated by means of squareroot-transformed data. The similarity of percentages (SIMPER) procedure was carried out to determine which fish taxa contributed most to dissimilarities among the different localities.

In order to determine the degree of correlation between 2 independent distance (dissimilarity or similarity) matrices, we applied the Mantel test (Mantel 1967), a randomization technique we used to test whether dissimilarity matrices of fish density (i.e. total assemblages, juveniles, subadults, and adults) and habitat variables (i.e. seagrass structure, physical water conditions, and habitat proximity) showed association between the different meadows. Distance matrices based on $X^{0.25}$-transformed fish density data were calculated on Bray-Curtis similarities, whereas distance matrices of $z$-transformed habitat and environmental variables (which here included physical water conditions and habitat proximity measurements) were made on Euclidean similarities measures. However, correlations among variables may be caused by joint correlations to a third variable. Therefore, residual correlations between similarity matrices which were found to be significantly correlated (before adjustment, see below, and with relatively high r-values, i.e. $>0.3$ ) using ordinary Mantel tests were subsequently analyzed with the partial Mantel test (Smouse et al. 1986). The significance of correlation coefficients (including both the ordinary and partial Mantel tests) was tested by random permutations (5000 iterations). In order to limit the probabilities of Type I errors, the significance levels were adjusted through the sequential Bonferroni procedure (Holm 1979). The ordinary Mantel tests were calculated using Mantel non-parametric test calculator version 2 (Liedloff 1999), and the R-package version 4.0 (Casgrain \& Legendre 2001) was used for partial Mantel tests.

\section{RESULTS}

\section{Seagrass habitat comparisons}

The structural complexity varied among seagrass localities (Table 1). Mean shoot density was significantly higher in Thalassia hemprichii sp.-dominated meadows (hereafter Thalassia-dominated meadows) compared with meadows dominated by Enhalus acoroides (hereafter Enhalus-dominated meadows). (ANOVA, $\mathrm{p}<0.05$; Table 2). In contrast, estimates of the mean shoot biomass were comparable with no significant differences between the 2 meadow types (Table 2), whereas the mean length of shoots, measured as canopy height, was significantly greater in Enhalusdominated than in Thalassia-dominated meadows. (ANOVA, p < 0.05; Table 2). For each structural complexity parameter, there was a strong significant difference among sites within each meadow type (ANOVA, $\mathrm{p}<0.001$; Table 2).

\section{Univariate patterns of fish assemblages}

A total of 6899 fishes belonging to 79 taxa (of which 71 have been identified to species level) were caught during the study (see Appendix 1 available in MEPS Supplementary Material at www.int-res.com/articles/ suppl/m363p241_app.pdf). Overall, the total number of fish species was highest in the mixed meadow, fol-

Table 1. Shoot density, shoot biomass, and canopy height (mean \pm SE) in seagrass meadows of Chwaka Bay $(n=20)$. DW: dry weight. See Fig. 1 legend for locality abbreviations

\begin{tabular}{|lrrr|}
\hline $\begin{array}{l}\text { Seagrass } \\
\text { habitat }\end{array}$ & $\begin{array}{c}\text { Shoot density } \\
\text { (no. shoots } \mathrm{m}^{-2} \text { ) }\end{array}$ & $\begin{array}{c}\text { Shoot biomass } \\
\left(\mathrm{g} \mathrm{DW} \mathrm{m}^{-2} \text { ) }\right.\end{array}$ & $\begin{array}{c}\text { Canopy height } \\
\text { (cm in length) }\end{array}$ \\
\hline E1 & $273.6 \pm 19.2$ & $105.1 \pm 8.5$ & $48.9 \pm 1.2$ \\
E2 & $424.0 \pm 27.5$ & $76.4 \pm 5.0$ & $27.9 \pm 1.3$ \\
E3 & $438.8 \pm 35.8$ & $94.5 \pm 5.5$ & $40.7 \pm 1.5$ \\
T1 & $1353.2 \pm 95.7$ & $61.8 \pm 8.3$ & $9.0 \pm 0.7$ \\
T2 & $1070.0 \pm 39.8$ & $88.9 \pm 4.4$ & $14.4 \pm 0.3$ \\
T3 & $768.0 \pm 78.9$ & $99.1 \pm 11.0$ & $21.3 \pm 1.3$ \\
M & $422.8 \pm 44.2$ & $94.5 \pm 14.6$ & $33.8 \pm 2.8$ \\
\hline
\end{tabular}

Table 2. Comparison of shoot density, shoot biomass, and canopy height in seagrass meadows dominated by Enhalus acoroides or Thalassia hemprichii by nested ANOVAs. Significant values $(p<0.0 .5)$ are shown in bold

\begin{tabular}{|c|c|c|c|c|c|c|c|c|c|c|}
\hline \multirow[t]{2}{*}{ Source of variation } & \multirow[t]{2}{*}{$\mathrm{df}$} & \multicolumn{3}{|c|}{ - Shoot density -} & \multicolumn{3}{|c|}{ — Shoot biomass — } & \multicolumn{3}{|c|}{ — Canopy height — } \\
\hline & & MS & $F$ & $\mathrm{p}$ & MS & $F$ & $\mathrm{p}$ & MS & $F$ & $\mathrm{p}$ \\
\hline Meadow type & 1 & 4936.6 & 17.38 & 0.014 & 9.2 & 0.51 & 0.513 & 175.5 & 12.35 & 0.025 \\
\hline Site (Meadow type) & 4 & 284.1 & 14.21 & $<0.001$ & 17.8 & 7.03 & $<0.001$ & 14.2 & 64.44 & $<0.001$ \\
\hline Residual & 114 & 20.0 & & & 2.5 & & & 0.2 & & \\
\hline
\end{tabular}


lowed by Enhalus- or Thalassia-dominated meadows, and lowest in the unvegetated area (Fig. 2, Appendix 1). Comparison between Enhalus- and Thalassiadominated meadows showed that both total density and species richness of fish were significantly higher in
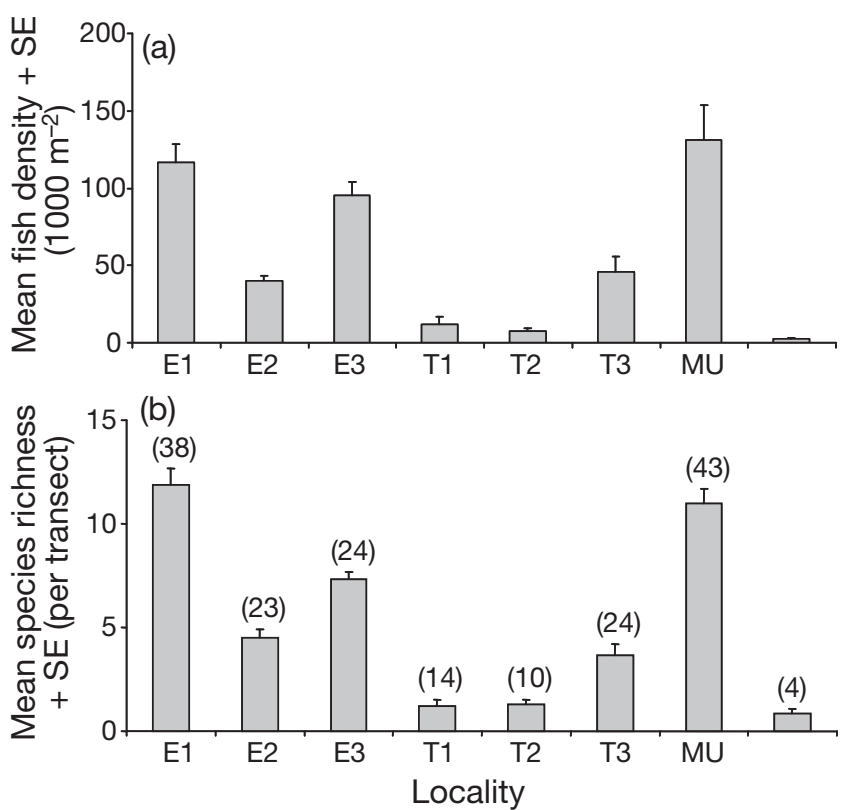

Fig. 2. (a) Mean density and (b) mean species richness of fish in all examined habitat localities. Error bars show SE. Numbers above the bars in (b) show the total number of fish species found in each locality during the entire study period. See Fig. 1 legend for locality abbreviations
Enhalus-dominated meadows, a result apparent at both the Meadow type and Site levels (Fig. 2, Table 3). For total fish biomass, there was also a significant difference between the 2 seagrass communities, but this was only evident for the Meadow type factor (Table 3). A significant interaction between Occasion and Site for both total fish density and total fish biomass indicated that a temporal component may have influenced the patterns (Table 3). Although not statistically tested, the mixed meadow showed a similar magnitude as E1 (the Enhalus-dominated site with the highest total density and species richness), while the unvegetated area was found to be sparser in numbers of species and individuals than any other seagrass locality (Fig. 2).

Mean fish densities of the different size classes varied inconsistently among localities (Fig. 3), which was confirmed by a chi-squared test of independence using pooled individual data $(\mathrm{df}=6, \mathrm{p}<0.05)$. In general, however, most individuals were juveniles (Fig. 3), and the species richness was proportionally higher for juveniles and subadults than for adult fish (Appendix 1). Comparing Enhalus-dominated meadows with those dominated by Thalassia revealed that juvenile and subadult fish densities did not significantly differ between meadow types, which likely depend on the strong significant variability at the Site level (Table 3). In contrast, there were significantly higher adult fish densities in the Enhalus-dominated meadows compared with the Thalassia-dominated meadows, partly because of the low variation among sites within each meadow type (Fig. 3, Table 3). Likewise, temporal vari-

Table 3. Summary of mixed-model ANOVAs of different fish variables in seagrass meadows dominated by Enhalus acoroides or Thalassia hemprichii. Significant values $(\mathrm{p}<0.05)$ are shown in bold

\begin{tabular}{|c|c|c|c|c|c|c|c|c|c|c|}
\hline \multirow{2}{*}{ Source of variation } & \multirow{2}{*}{$\mathrm{df}$} & \multicolumn{3}{|c|}{ Total fish density } & \multicolumn{3}{|c|}{ Total fish biomass } & \multicolumn{3}{|c|}{ Fish species richness } \\
\hline & & MS & $F$ & $\mathrm{p}$ & MS & $F$ & $\mathrm{p}$ & MS & $F$ & $\mathrm{p}$ \\
\hline Meadow type & 1 & 1.032 & 8.58 & 0.043 & 8.501 & 13.59 & 0.021 & 0.209 & 9.77 & 0.035 \\
\hline Site (Meadow type) & 4 & 0.120 & 8.96 & $<0.001$ & 0.626 & 3.25 & 0.051 & 0.021 & 17.05 & $<0.001$ \\
\hline Occasion & 3 & 0.002 & 0.12 & 0.949 & 0.011 & 0.06 & 0.981 & 0.001 & 1.04 & 0.411 \\
\hline Occasion $\times$ Meadow type & e 3 & 0.004 & 0.32 & 0.811 & 0.120 & 0.62 & 0.614 & 0.001 & 0.53 & 0.668 \\
\hline $\begin{array}{l}\text { Occasion } \times \text { Site } \\
\text { (Meadow type) }\end{array}$ & 12 & 0.013 & 2.60 & 0.004 & 0.193 & 4.00 & $<0.001$ & 0.001 & 1.51 & 0.131 \\
\hline Residual & 120 & 0.005 & & & 0.048 & & & 0.001 & & \\
\hline \multirow{2}{*}{ Source of variation } & \multirow[t]{2}{*}{$\mathrm{df}$} & \multicolumn{3}{|c|}{ Juvenile fish density } & \multicolumn{3}{|c|}{ Subadult fish density } & \multicolumn{3}{|c|}{ Adult fish density } \\
\hline & & MS & $F$ & $\mathrm{p}$ & MS & $F$ & $\mathrm{p}$ & MS & $F$ & $\mathrm{p}$ \\
\hline Meadow type & 1 & 0.733 & 7.29 & 0.054 & 0.292 & 7.32 & 0.054 & 0.124 & 14.27 & 0.019 \\
\hline Site (Meadow type) & 4 & 0.101 & 12.52 & $<0.001$ & 0.040 & 16.17 & $<0.001$ & 0.009 & 2.14 & 0.139 \\
\hline Occasion & 3 & 0.003 & 0.38 & 0.771 & 0.002 & 0.72 & 0.557 & 0.002 & 0.38 & 0.771 \\
\hline Occasion $\times$ Meadow type & e 3 & 0.002 & 0.21 & 0.885 & 0.001 & 0.41 & 0.747 & 0.012 & 2.96 & 0.075 \\
\hline $\begin{array}{l}\text { Occasion } \times \text { Site } \\
(\text { Meadow type) }\end{array}$ & 12 & 0.008 & 2.01 & 0.029 & 0.002 & 1.76 & 0.062 & 0.004 & 2.31 & 0.011 \\
\hline Residual & 120 & 0.004 & & & 0.001 & & & 0.002 & & \\
\hline
\end{tabular}




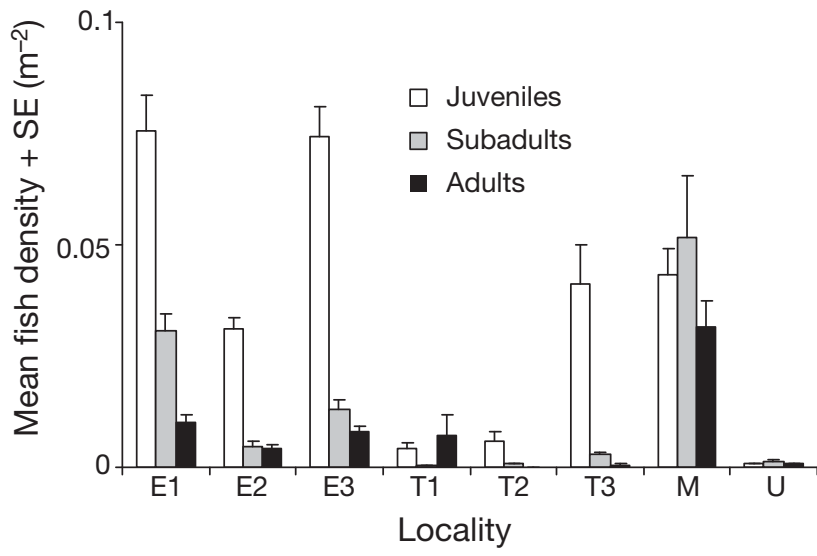

Fig. 3. Mean density of juvenile, subadult, and adult life stages (size classes) of fish. Error bars show SE. See Fig. 1 legend for locality abbreviations

ability may affect juvenile and adult fish densities as there were significant interactions between Occasion and Site (Table 3). The mixed meadow showed the highest fish densities for both subadults and adults, whereas the density of juveniles was similar to other meadows dominated by Enhalus or Thalassia (Fig. 3). Due to the low total numbers of fish in the unvegetated area, each of the 3 size-class density estimates was negligible (Fig. 3).

The classification of fish into habitat preference groups showed that, in terms of percentage of the number of species, most were coral-seagrass-associated, while fewer were seagrass residents or generalists (Fig. 4a). Mangrove-seagrass-associated fish species were relatively common at only 2 Thalassia-dominated sites, i.e. T1 and T2 (Fig. 4a). In contrast to the number of species, most fish individuals were recorded as seagrass residents or coral-seagrass-associated (Fig. 4b). The only exception was shown for 1 of the Thalassiadominated localities (T1), which mainly comprised individuals of the mangrove-seagrassassociated fish group (Fig. 4b). The unvegetated area (U) differs from all seagrass localities, and showed a fish assemblage with species mainly associated to bare sand or mud substratum (Fig. 4).

An examination of associations between fish variables and different predictor variables using stepwise multiple regression analysis revealed that only 1 predictor variable was significantly related to each dependent fish variable (Table 4). Seagrass canopy height explained a high proportion of variability for total fish density, total fish biomass, species richness, and
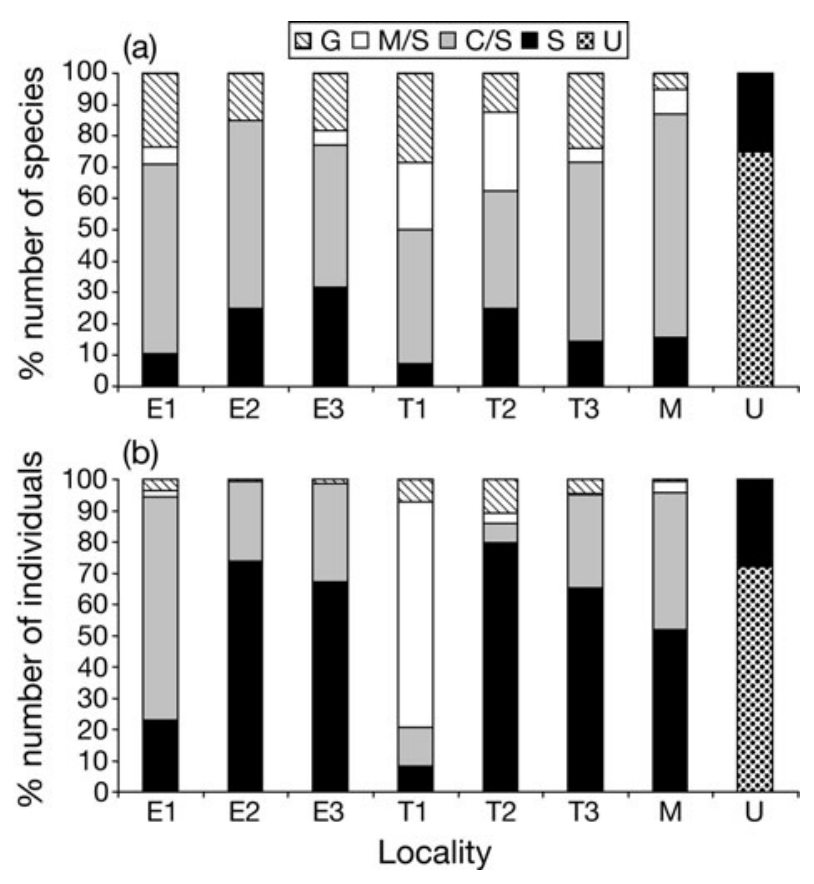

Fig. 4. Percentage of number of (a) species and (b) individuals of fish distinguished (based on Froese \& Pauly 2005) into habitat preference groups as G (generalists), M/S (mangrove-seagrass-associated fish), C/S (coral-seagrass-associated fish), S (seagrass residents), and U (fish exclusively associated with unvegetated habitat). See Fig. 1 legend for locality abbreviations

juvenile fish density, whereas subadult and adult fish densities were both significantly correlated with estimated water depth (Table 4). ANCOVA showed that the effect of canopy height (covariate) on total fish density (dependent variable) in the regression analysis could be removed from the unexplained variability as it is separated from the effect of meadow type, i.e. the species composition of seagrass meadows $\left(F_{2,4}=55.2\right.$, $\mathrm{p}<0.001)$.

Table 4. Results of stepwise multiple linear regression analysis (using forward selection procedure) showing variables significantly predicting species richness, density (all specimens, juveniles, subadults, and adults) and biomass of fish (all specimens). Nonsignificant predictor variables omitted from all regression models were shoot density, shoot biomass, water temperature, water salinity, distance to mangrove, and distance to coral reef

\begin{tabular}{|lccccc|}
\hline Dependent variable & Intercept & \multicolumn{2}{c}{$\begin{array}{c}\text { Predictor coefficient } \\
\text { Canopy }\end{array}$} & $\mathrm{R}^{2}$ & $\mathrm{p}$ \\
& & Water & & & \\
height & depth & & \\
\hline Total fish density & -0.022 & 0.003 & & 0.77 & 0.0092 \\
Total fish biomass & -0.169 & 0.022 & & 0.91 & 0.0009 \\
Fish species richness & -0.005 & 0.001 & & 0.83 & 0.0045 \\
Juvenile fish density & -0.014 & 0.002 & & 0.90 & 0.0012 \\
Subadult fish density & -0.051 & & 0.034 & 0.77 & 0.0098 \\
Adult fish density & -0.029 & & 0.019 & 0.84 & 0.0036 \\
\hline
\end{tabular}




\section{Multivariate patterns of fish assemblages}

A 2-way crossed ANOSIM analyzing density-based fish assemblage structure revealed significant separation among localities (global $\mathrm{R}=0.70, \mathrm{p}<0.001$ ) as well as among size classes (global $\mathrm{R}=0.84, \mathrm{p}<0.001$ ), and supports the clear visible patterns in the NMDS ordination plots (Fig. 5). Pairwise habitat comparisons, however, showed that the 3 localities T1, T2, and U were not significantly different from each other $(\mathrm{R}=$ 0.03 to $0.37, \mathrm{p}=0.07$ to 0.50 ). Analogous to the results of density data, an additional 2-way crossed ANOSIM of fish assemblage structure based on biomass also showed significant differences among localities (global $\mathrm{R}=0.82$, $\mathrm{p}<0.001$ ) and among size classes (global $\mathrm{R}=0.82, \mathrm{p}<0.001$ ).

SIMPER analyses showed that the most abundant species, Leptoscarus vaigiensis, a seagrass resident (see Appendix 1), was also the species that contributed most to dissimilarities in assemblage structure among localities for both total fish density and total fish biomass (Table 5). Furthermore, Cheilio inermis and Siganus sutor, 2 other fish species of high relative abundance and associated with coral-reef and seagrass habitats (Appendix 1), also contributed a relatively large part to the total dissimilarity of both total density and total biomass (Table 5). Due to a generally
Table 5. Fish species contributing (by \%) most to dissimilarities (cumulative limit of $90 \%$ ) among sampling sites (described in Fig. 1 legend) in the SIMPER analysis on density (all specimens, juveniles, subadults, and adults) and biomass data (all specimens)

\begin{tabular}{|c|c|c|c|c|c|}
\hline \multirow{2}{*}{ Species } & \multicolumn{2}{|c|}{$\longrightarrow$ All fish -} & \multirow{2}{*}{$\begin{array}{c}\text { Juvenile } \\
\text { fish } \\
\text { density }\end{array}$} & \multirow{2}{*}{$\begin{array}{l}\text { Subadult } \\
\text { fish } \\
\text { density }\end{array}$} & \multirow{2}{*}{$\begin{array}{l}\text { Adult } \\
\text { fish } \\
\text { density }\end{array}$} \\
\hline & Density & Biomass & & & \\
\hline Average similarity & 25.37 & 24.08 & 35.62 & 16.17 & 19.04 \\
\hline Leptoscarus vaigiensis & 45.46 & 49.20 & 57.84 & 17.88 & \\
\hline Cheilio inermis & 11.82 & 10.43 & 16.07 & & \\
\hline Siganus sutor & 5.51 & 6.89 & 6.66 & 1.90 & \\
\hline Canthigaster valentini & 4.74 & 2.98 & & 23.10 & \\
\hline Syngnatoides biaculeatus & 3.20 & 3.56 & & 12.49 & 30.30 \\
\hline Calotomus spinidens & 3.16 & 2.24 & 4.31 & & \\
\hline Scarus psittacus & 2.92 & 2.24 & 3.88 & & \\
\hline Chrysiptera annulata & 2.79 & 2.99 & & & 31.69 \\
\hline Stethojulis albovittata & 2.32 & & 2.30 & 5.14 & \\
\hline Canthigaster solandri & 2.28 & 2.13 & & 11.56 & \\
\hline Fowleria aurita & 1.80 & 1.35 & & 9.43 & 4.93 \\
\hline Pomacentrus trilineatus & 1.41 & 1.65 & & & 16.40 \\
\hline Lutjanus fluviflamma & 1.16 & 2.22 & & & \\
\hline Petroscirtes mitratus & 0.89 & & & 3.99 & \\
\hline Arothron hispidus & 0.85 & 2.25 & & & \\
\hline Arnoglossus capensis & & & & 2.68 & \\
\hline Apogon nigripes & & & & 2.53 & 2.87 \\
\hline Hippichtys spicifer & & & & & 2.88 \\
\hline Dascyllus aruanus & & & & & 2.54 \\
\hline
\end{tabular}

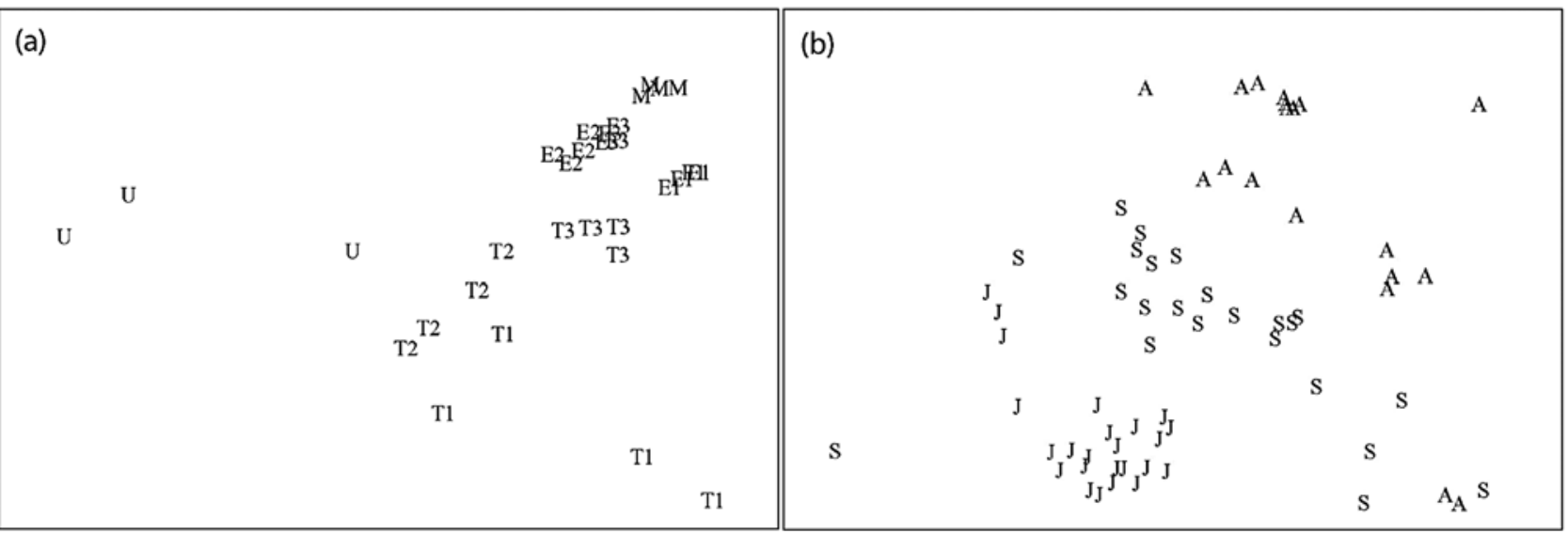

Fig. 5. Non-parametric multidimensional scaling (NMDS) ordinations of fish assemblage structure, separated into (a) habitats (see Fig. 1 legend for locality abbreviations) and (b) size classes ( $\mathrm{J}=$ juveniles, $\mathrm{S}=$ subadults, $\mathrm{A}=$ adults). Both plots are based on the Bray-Curtis similarities index using square-root-transformed density data. Statistical stress is 0.09 (a) and 0.11 (b), respectively. T1 and U were excluded from (b) because their fish assemblage structures were so different from the other sites that the plot would be difficult to interpret if these sites were included 
Distance-based Mantel correlation analyses showed that the structural composition of fish was significantly affected by the distance from each seagrass locality to neighboring mangrove and coral-reef habitats (Mantel test, $\mathrm{r}=0.48$ to $0.80, \mathrm{p}<0.001$; Table 6 ), and these effects remained after correcting for other significant predictor variables, i.e. shoot density and canopy height (partial Mantel test, Table 7). Furthermore, the ordinary Mantel test revealed that seagrass shoot den-

Table 6. Distance-based Mantel correlation analysis on the relationships between data on seagrass structural complexity (shoot density, shoot biomass, and canopy height), physical water conditions (temperature, salinity, and depth), or the distance from a seagrass locality to a neighboring habitat (i.e. mangrove and coral reef), and fish density data. Significant levels were adjusted (Adj) for multiple comparisons using the sequential Bonferroni procedure (see 'Materials and methods' for further details). Significant correlations $(\mathrm{p}<0.05)$ before adjustment are shown in bold. ns = not significant. *Significant after Bonferroni adjustment

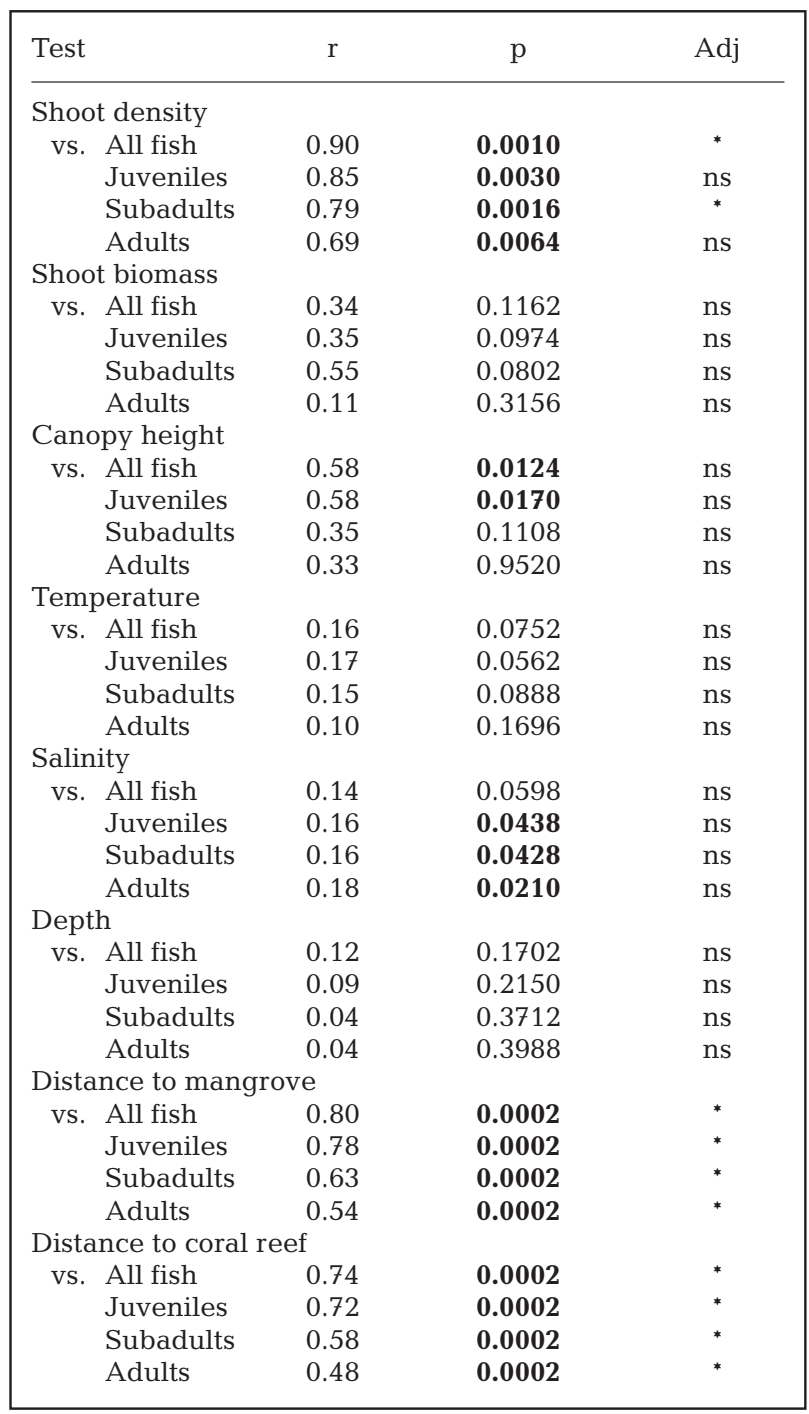

sity and canopy height were both to some extent correlated with fish assemblage composition (Table 6). The partial Mantel test, however, showed that the effects of canopy height on fish assemblage structure disappear if the mangrove-seagrass distance variable is corrected for, whereas significant effects of shoot density remain, even after correcting for the distance from seagrass localities to both mangrove and coral-reef habitats, respectively. The trend is that the effect of shoot density is slightly stronger on adults than on juveniles, while the effect of distance to a neighboring habitat is stronger for juveniles than for adults (Table 6). In general, juvenile assemblage structure variables showed higher correspondences (r-values) with predictor variables than did subadult and adult fish assemblage structure variables (Tables $6 \& 7$ ).

\section{DISCUSSION}

Several key factors have been suggested to influence spatial patterns and variability of seagrass fish assemblages, including fine-scale within-meadow characteristics (e.g. habitat complexity; Heck \& Orth 1980, Bell \& Westoby 1986a) as well as broad landscape-scale attributes (e.g. habitat connectivity; Baelde 1990, Jelbart et al. 2007). The present study is one of few that have considered the relative importance of multiple explanatory factors of various spatial scales in structuring fish assemblage composition of seagrass meadows, and that focused on different life stages.

\section{Effects of fine-scale habitat complexity and physical water properties}

A strong positive relationship was found between seagrass canopy height and juvenile fish density. A positive correlation with canopy height was also found for total density, total biomass, and species richness of fish, relationships which were most likely effects of the large proportion of juvenile fish. One possible explanation for the strong relationship between canopy height and juvenile fish density is that a higher seagrass canopy favors survival of young fish via enhanced sheltering capacity to avoid predators (Heck \& Orth 1980), whereas another explanation is linked to the positive response of greater food availability within structurally more complex seagrass meadows (Connolly 1994b). In contrast to our study, earlier surveys correlating abundance and species richness of fish with seagrass shoot length displayed unpredictable results with no consistent patterns (e.g. Bell \& Westoby 1986a, Sogard et al. 1987, Connolly 1994a). A reason for the rather unique observation in the present study, 
Table 7. Correlation analysis using partial Mantel tests between similarity matrices found to be significantly correlated using ordinary Mantel test (see Table 6). Significant correlations $(\mathrm{p}<0.05)$ are shown in bold

\begin{tabular}{|c|c|c|c|}
\hline Test & & $\mathrm{r}$ & $\mathrm{p}$ \\
\hline \multicolumn{4}{|l|}{ All fish } \\
\hline \multirow[t]{2}{*}{ vs. Canopy height } & (Distance to mangrove) & -0.02 & 0.4640 \\
\hline & (Distance to coral reef) & 0.43 & 0.0002 \\
\hline \multirow[t]{2}{*}{ Shoot density } & (Distance to mangrove) & 0.32 & 0.0002 \\
\hline & (Distance to coral reef) & 0.57 & 0.0002 \\
\hline \multirow[t]{2}{*}{ Distance to mangrove } & (Canopy height) & 0.65 & 0.0002 \\
\hline & (Shoot density) & 0.10 & 0.1234 \\
\hline \multirow[t]{2}{*}{ Distance to coral reef } & (Canopy height) & 0.64 & 0.0002 \\
\hline & (Shoot density) & 0.22 & 0.0194 \\
\hline \multicolumn{4}{|l|}{ Juveniles } \\
\hline \multirow[t]{2}{*}{ vs. Canopy height } & (Distance to mangrove) & -0.06 & 0.2701 \\
\hline & (Distance to coral reef) & 0.38 & 0.0002 \\
\hline \multirow{2}{*}{ Shoot density } & (Distance to mangrove) & 0.16 & 0.0126 \\
\hline & (Distance to coral reef) & 0.47 & 0.0002 \\
\hline \multirow{2}{*}{ Distance to mangrove } & (Canopy height) & 0.65 & 0.0002 \\
\hline & (Shoot density) & 0.24 & 0.0109 \\
\hline \multirow[t]{2}{*}{ Distance to coral reef } & (Canopy height) & 0.62 & 0.0002 \\
\hline & (Shoot density) & 0.26 & 0.0109 \\
\hline \multicolumn{4}{|l|}{ Subadults } \\
\hline \multirow[t]{2}{*}{ vs. Canopy height } & (Distance to mangrove) & -0.11 & 0.0966 \\
\hline & (Distance to coral reef) & 0.21 & 0.0158 \\
\hline \multirow[t]{2}{*}{ Shoot density } & (Distance to mangrove) & 0.32 & 0.0002 \\
\hline & (Distance to coral reef) & 0.44 & 0.0002 \\
\hline \multirow[t]{2}{*}{ Distance to mangrove } & (Canopy height) & 0.52 & 0.0002 \\
\hline & (Shoot density) & -0.06 & 0.2477 \\
\hline \multirow[t]{2}{*}{ Distance to coral reef } & (Canopy height) & 0.47 & 0.0002 \\
\hline & (Shoot density) & 0.07 & 0.2451 \\
\hline \multicolumn{4}{|l|}{ Adults } \\
\hline \multirow{2}{*}{ vs. Canopy height } & (Distance to mangrove) & -0.01 & 0.4873 \\
\hline & (Distance to coral reef) & 0.23 & 0.0076 \\
\hline \multirow[t]{2}{*}{ Shoot density } & (Distance to mangrove) & 0.36 & 0.0002 \\
\hline & (Distance to coral reef) & 0.43 & 0.0002 \\
\hline \multirow[t]{2}{*}{ Distance to mangrove } & (Canopy height) & 0.38 & 0.0002 \\
\hline & (Shoot density) & -0.16 & 0.0220 \\
\hline \multirow[t]{2}{*}{ Distance to coral reef } & (Canopy height) & 0.35 & 0.0016 \\
\hline & (Shoot density) & -0.02 & 0.4391 \\
\hline
\end{tabular}

Using shoot density as predictor variable, we found no significant association with any univariate fish variable. However, multivariate patterns of fish assemblage structure were correlated with both shoot density and (although weaker) canopy height, respectively. In contrast to shoot density and canopy height, seagrass biomass has been questioned as a complexity index as it gives merely a simple species-area relationship (Attrill et al. 2000). In light of this, it has been demonstrated that the presence of habitat structure per se can be more important than inherent structural characteristics in influencing fish density patterns (Jenkins \& Wheatley 1998). However, our study showed significant differences among seagrass localities for most examined fish variables, even though the mean seagrass shoot biomass did not. Thus, we found no significant fish-habitat relationship using shoot biomass as habitat (predictor) variable. Our results contrast with those of others (e.g. Attrill et al. 2000, Hovel et al. 2002, Sirota \& Hovel 2006), who found that seagrass biomass influences epifaunal community patterns (although fish was only part of their respective study communities). Nevertheless, fish density and species richness in the unvegetated sand flat were much lower than in all seagrass habitats, which supports not only the wellestablished assumption that seagrass meadows are comprised of more abun-

i.e. that the seagrass structure seems to have a major and predictable impact on the composition of fish assemblages, might be that the studied embayment (Chwaka Bay) consists of highly diverse seagrass systems with a great variability in structural complexity (long plants intermingling with short plants), while other studies have often dealt with strict monospecific meadows with a low variability in seagrass shoot length. Hence, it seems that the structural complexity of diverse seagrass systems such as those found widely within the western Indian Ocean region may induce a strong effect on fish assemblage composition. However, a response of seagrass canopy height seems likely to be species-specific (e.g. Bell \& Westoby 1986a), explicit for an organism's life stage (the present study), and/or dependent on an underlying trade-off strategy weighing optimal foraging and sheltering efficiency (Dahlgren \& Eggleston 2000). dant and diverse assemblages than unvegetated areas in general (Bell \& Pollard 1989), but also that the presence of structure per se attracts fish (Bell et al. 1987).

In contrast to juvenile fish, the numbers of both adult and subadult individuals were positively correlated with estimated water depth. These correlations may arise because the occurrence of large fish primarily depends on tidal regime and species-specific mobility, and large fish have a preference for slightly deeper subtidal seagrass habitats. Such a deeper seagrass meadow may provide a suitable environment for foraging concurrently with an increased space for protection against more deep-living piscivores. The habitats of greater depths are located closer to the coral reef, which may have also affected the density of adult and subadult fish due to diel or ontogenetic migration between seagrass habitats and the coral reef (Robblee \& Zieman 1984, Nagelkerken et al. 2001). For the other 
physical parameters, i.e. water temperature and salinity, we found no significant correlations with fish variables using either uni- or multivariate analyses. The salinity factor might have had an impact if we had also investigated seagrass areas closer to the mangrove habitat during a period of heavy rains, which may have caused a pronounced salinity gradient (Mohammed 1998).

\section{Effect of landscape configuration}

The proximity of neighboring shallow-water habitats may have strong effects on the structuring of fish assemblages (Dorenbosch et al. 2007, Grober-Dunsmore et al. 2007). Prior to the present study, significant shifts in seagrass fish abundance and assemblage structure were correlated with the distance from seagrass meadows to both mangrove (Jelbart et al. 2007) and coral-reef habitats (Dorenbosch et al. 2004b). Even though multiple regression analyses did not show any significant relationships with fish density, biomass, or species richness, our study did show distinct multivariate patterns with a structural organization of fish assemblages, irrespective of size class, that was significantly correlated with the distance from seagrass meadows to neighboring mangrove and coral-reef habitats, suggesting that landscape configuration and connectedness among adjacent habitats are essential factors shaping fish assemblage composition.

Lugendo et al. (2005) examined habitat utilization of juvenile fish in Chwaka Bay and found a high number of species in seagrass channels. They suggested that this high diversity was due to the geographic location of seagrass habitats, in between an extensive mangrove forest and a deeper coral reef, and that the seagrass channels may operate as tide-related refuges (Dorenbosch et al. 2004a) or as corridors for transient fish undertaking ontogenetic migration from mangrove to coral-reef habitat (Nagelkerken et al. 2000). Our study was carried out in large, rather homogeneous (but still of different structural complexity) seagrass meadows surrounding those highly heterogeneous channel systems, but we still found a relatively high number of fish species compared with other trawling studies covering a similar seagrass area (e.g. Gullström et al. 2002, Hyndes et al. 2003). We suggest that this depends not only on local-scale variability of the seagrass structure, but also on various characters of the bay itself, among them its richness and spatial arrangement of adjacent shallow-water habitats within the landscape context. For instance, the proximity among embayment habitats influences the importance of home-range properties and species-specific requirements of mobile faunal organisms (Boström et al. 2006).
Previous studies have shown that seagrass fish assemblages may rely on the location of seagrass meadows within an estuary or shallow embayment (Bell et al. 1988, Baelde 1990, Jelbart et al. 2007). Similar to Baelde (1990), we found striking differences in fish assemblage structure between a seagrass site (T1) near a mangrove forest (with high abundances of fish species usually inhabiting mangroves, e.g. Sphaeramia orbicularis, Novaculichthys macrolepidotus, Pelates quadrilineatus, and Gerres oyena) and seagrass sites (E1, E2, E3, and M) situated closer to a coral reef (with their many reef-associated species belonging to e.g. Labridae and Pomacentridae). The most likely reason for the dominance of mangrove-seagrass-associated fish at $\mathrm{T} 1$ is that this specific meadow functions as a tidal transitional zone between the mangrove forest and a deeper embayment channel located next to T1. It may also depend on a rational assumption that the numbers of species and individuals of mangrove-seagrass-associated fish will increase in seagrass meadows closer to mangrove areas (as shown in the present study), although the relationship as a function of distance between the 2 habitats is not very clear (Fig. 6). However, there might be a threshold distance - probably highly variable depending on local tidal regime and embayment characteristics - in which fishes regularly migrate between mangrove and seagrass habitats. In our study area, it seems as if a threshold distance could have an intercept of about 1 and $3 \mathrm{~km}$ estimated from the mangrove area (Fig. 6), but for a complete understanding this has to be investigated with a larger number of replicate sites at different distances. In addition, numerous coral-seagrass-associated fish species may migrate regularly within the shallow-water environment, and it is likely that potential prevailing migration patterns are strongly influenced by the distance to the coral reef (Baelde 1990). Hence, this might explain why high densities of this group of fish species (coral-seagrass-associated) were more often found in the seaward (and slightly deeper), mixed and Enhalus-dominated localities than in e.g. the interior, Thalassi-dominated habitat T1. However, the total density of coral-seagrass-associated fish is not clearly divergent in different parts of the embayment (Fig. 6).

\section{General patterns of fish assemblage composition}

Our study showed that the assemblage structure of fish varied spatially among seagrass habitat types, with the mixed meadow and meadows dominated by Enhalus acoroides displaying a higher fish density and diversity than meadows dominated by Thalassia hemprichii. The result was similar to previous findings by 

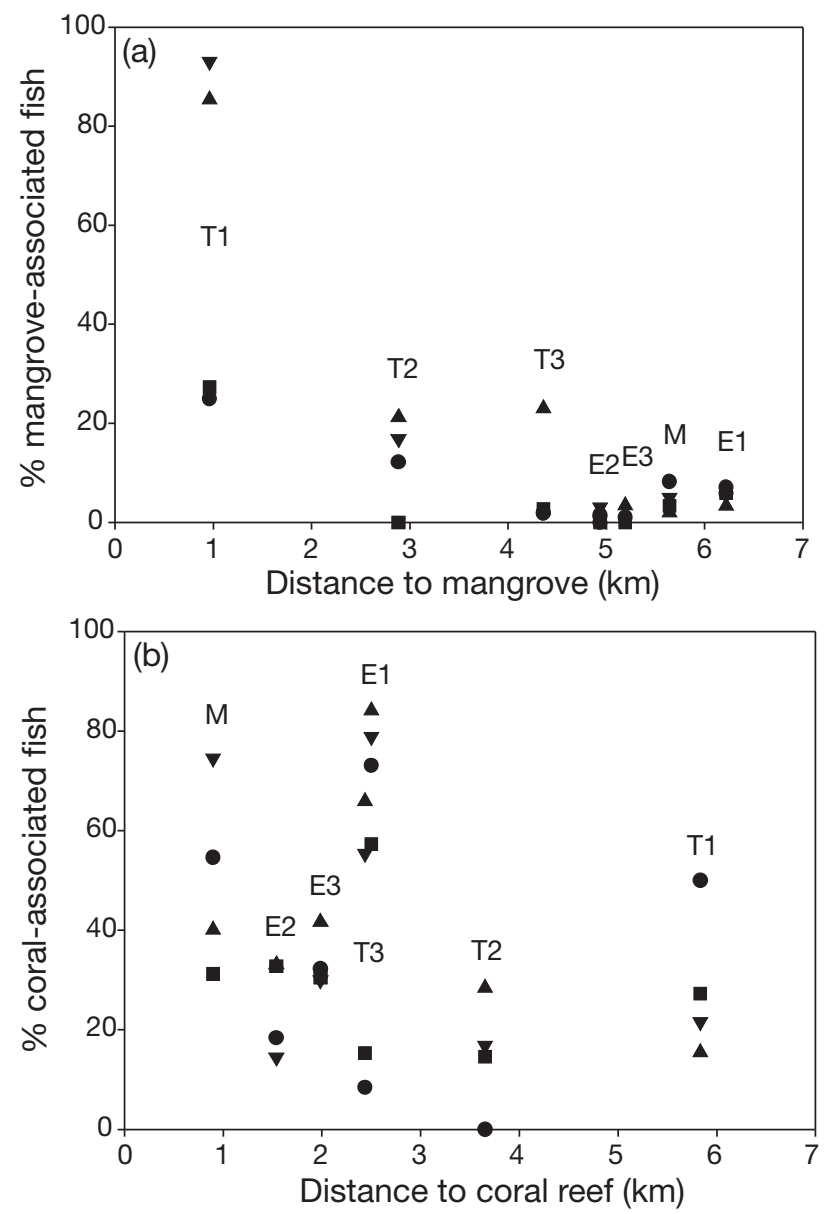

Fig. 6. Relationships between the percentage contribution of (a) mangrove-associated fish (i.e. mangrove-seagrassassociated fish and generalists) and (b) coral-associated fish (i.e. coral-seagrass-associated fish and generalists), and the distance from seagrass sampling locality (denoted by letter) to mangrove and coral-reef habitats, respectively. Symbols represent different sampling occasions (for details see 'Materials and methods'). •: Occasion 1, $\mathbf{n}$ : Occasion 2, $\mathbf{v}$ : Occasion 3,

$\Delta$ : Occasion 4. See Fig. 1 legend for locality abbreviations

Nakamura \& Sano (2004) who compared Enhalus- and Thalassia-dominated meadows, and was likely due to a combination of factors, of which the proximity to a neighboring habitat and seagrass characteristics were interpreted as important. For seagrass variables, the influence of shoot density was stronger than that of canopy height, which therefore seems to have a subordinate role as predictor variable. From a life stage perspective, the influence of habitat proximity was slightly stronger for juveniles than for adults, whereas the influence of shoot density was stronger for adults than for juveniles. This makes sense, considering the difference in swimming capacity and predation risk between the different life stages. Nevertheless, we do acknowledge that these conclusions must be interpreted with some caution, since the actual number of seagrass localities was relatively small, even though several variables were measured. Hence, there are of course some variables that are correlated, and thus causes and effects may be confounded, although the partial Mantel test is used as a way of decreasing this risk (see Table 7).

The strong variation in fish assemblage structure was primarily driven by the large differences in numbers of juvenile seagrass residents and coral-seagrassassociated fish of all life stages. Within the group of seagrass residents, most individuals were herbivores, comprising $46 \%$ of all specimens, and since a large part belongs to seagrass-grazing parrotfish, these may provide an important trophic link within the seagrass food web (Kirsch et al. 2002). In contrast to the density patterns observed, the number of herbivorous fish species was very low (only 7 species recorded), and the majority of species (and also a large proportion of individuals) were carnivorous or omnivorous coralseagrass-associated fish. Overall, it is suggested that the diverse seagrass habitats of this embayment are affected in a complex way with trophic interactions determined by species- and life stage-specific preferences for food and shelter (sensu Shulman 1985) as well as by the intensity of cross-habitat energy exchange (sensu Valentine et al. 2007).

\section{Potential nursery function and implications for conservation}

Numerous studies have shown that seagrass meadows contain high densities of juvenile fish in relation to other shallow-water habitats (e.g. Parrish 1989, Edgar \& Shaw 1995, Nagelkerken et al. 2001). This is a reason why seagrass meadows are suggested to be important nursery areas, either as key nurseries (Bell \& Pollard 1989) or as part of multiple nearshore nursery habitats (together with e.g. mangroves and shallow coral reefs; Nagelkerken et al. 2000). In seagrass areas of our study, we recognized high densities of juveniles (75\% of all fishes) in comparison with the number of subadult $(16 \%)$ and adult individuals $(9 \%)$. Out of 71 fish species (i.e. all fish identified to species level), 63 species were dominated by juvenile and/or subadult individuals, including 25 species that were almost exclusively restricted to the juvenile size class. This predominance of young fish in seagrass meadows has been found earlier in the studied embayment (Dorenbosch et al. 2005a, Lugendo et al. 2005) as well as elsewhere in the western Indian Ocean region (e.g. Gell \& Whittington 2002, Gullström et al. 2002, Dorenbosch et al. 2005b). Lugendo et al. (2005) suggested that similar mechanisms are at work in the western Indian Ocean as in embayment habitats of the more 
extensively studied Caribbean Sea, where shallow marine embayment systems are entirely dominated by fish of juvenile life stages and juveniles use seagrass areas as one of multiple nearshore nursery habitats. Hence, seagrass meadows in the western Indian Ocean region may also have a significant role as nursery environments for juvenile fish, although this has not yet been completely tested (Beck et al. 2001).

Results from the present study indicate that patterns of abundance and distribution of seagrass fish assemblages are influenced by factors on multiple spatial scales. Hence, for management and conservation of nearshore seagrass areas (e.g. selection of marine protected areas, MPAs), our study highlights the importance of the need to jointly consider local seagrass characteristics and landscape configuration. From a general coastal management perspective, the proximity of neighboring habitats is relevant when determining geographic boundaries of MPAs (Grober-Dunsmore et al. 2007). However, faunal assemblage compositions are not only affected by the distance between different habitats, but also the size (Russell et al. 2005) and matrix of neighboring habitats (Tanner 2006).

In summary, our findings emphasize the importance of focusing on various ecological traits, environmental conditions, and life-history stages at multiple spatial scales to better understand fish-habitat relationships in shallow seagrass meadows. For maintenance of diverse and abundant seagrass fish communities, we suggest that protection and preservation of seagrass meadows should be carefully considered by their structural complexity, species composition, and position within the landscape context.

Acknowledgements. We thank M. Manzi and M. N. Muhammed for excellent support during the whole field period, and L. Adelsköld, M. de la Torre-Castro, J. S. Eklöf, and S. A. S. Yahya for help during part of the field work. The Institute of Marine Science (University of Dar es Salaam) at Zanzibar provided research facilities and we appreciate the support given by N. Jiddawi, and A. Dubi. The manuscript was greatly improved after beneficial discussions with and/or comments from M. E. Asplund, M. Björk, C. Boström, J. S. Eklöf, L. Hammar, G. A. Hyndes, N. Kautsky, M. Lindegarth, B. Lundén, P.-O. Moksnes, A. Norkko, P. Thor, and 3 anonymous reviewers. Many thanks to M. Lindegarth for statistical advice. The study was supported by the Swedish International Development Cooperation Agency (Sida) through the Sida/SAREC Bilateral Marine Science Programme between Sweden and Tanzania for research in marine zoology and botany, and the Sida/SAREC-funded project 'Changes in tropical seagrass beds induced by eutrophication'.

\section{LITERATURE CITED}

Adams SM (1976) The ecology of eelgrass, Zostera marina (L.), fish communities. I. Structural analysis. J Exp Mar Biol Ecol 22:269-291

Attrill MJ, Strong JA, Rowden AA (2000) Are macroinverte- brate communities influenced by seagrass structural complexity? Ecography 23:114-121

Baelde P (1990) Differences in the structures of fish assemblages in Thalassia testudinum beds in Guadeloupe, French West Indies, and their ecological significance. Mar Biol 105:163-173

> Beck MW, Heck KL Jr, Able KW, Childers DL and others (2001) The identification, conservation, and management of estuarine and marine nurseries for fish and invertebrates. Bioscience 51:633-641

Bell JD, Pollard DA (1989) Ecology of fish assemblages and fisheries associated with seagrasses. In: Larkum AWD, McComb AJ, Shepherd SA (eds) Biology of seagrasses a treatise on the biology of seagrasses with special reference to the Australian region. Elsevier, Amsterdam, p 565-609

Bell JD, Westoby M (1986a) Importance of local changes in leaf height and density to fish and decapods associated with seagrasses. J Exp Mar Biol Ecol 104:249-274

Bell JD, Westoby M (1986b) Variation in seagrass height and density over a wide spatial scale: effects on common fish and decapods. J Exp Mar Biol Ecol 104:275-295

Bell JD, Westoby M, Steffe AS (1987) Fish larvae settling in seagrass: do they discriminate between beds of different leaf density? J Exp Mar Biol Ecol 111:133-144

Bell JD, Steffe AS, Westoby M (1988) Location of seagrass beds in estuaries: effects on associated fish and decapods. J Exp Mar Biol Ecol 122:127-146

Benedetti-Cecchi L, Bertocci I, Micheli F, Maggi E, Fosella T, Vaselli S (2003) Implications of spatial heterogeneity for management of marine protected areas (MPAs): examples from assemblages of rocky coasts in the northwest Mediterranean. Mar Environ Res 55:429-458

Blaber SJM, Brewer DT, Salini JP, Kerr JD, Conacher C (1992) Species composition and biomasses of fishes in tropical seagrasses at Groote Eylandt, northern Australia. Estuar Coast Shelf Sci 35:605-620

> Boström C, Jackson EL, Simenstad CA (2006) Seagrass landscapes and their effects on associated fauna: a review. Estuar Coast Shelf Sci 68:383-403

Casgrain P, Legendre P (2001) The R-package for multivariate and spatial analysis. Département de Sciences Biologiques, Université de Montréal, Montreal

Cederlöf U, Rydberg L, Mgendi M, Mwaipopo O (1995) Tidal exchange in a warm tropical lagoon: Chwaka Bay, Zanzibar. Ambio 24:458-464

Clarke KR, Warwick RM (1994) Changes in marine communities: an approach to statistical analysis and interpretation. Plymouth Marine Laboratory, Plymouth

> Connolly RM (1994a) Removal of seagrass canopy: effects on small fish and their prey. J Exp Mar Biol Ecol 184:99-110

> Connolly RM (1994b) The role of seagrass as preferred habitat for juvenile Sillaginodes punctata (Cuv. \& Val.) (Sillaginidae, Pisces): habitat selection or feeding? J Exp Mar Biol Ecol 180:39-47

> Connolly RM, Hindell JS (2006) Review of nekton patterns and ecological processes in seagrass landscapes. Estuar Coast Shelf Sci 68:433-444

Dahlgren CP, Eggleston DB (2000) Ecological processes underlying ontogenetic habitat shifts in a coral reef fish. Ecology 81:2227-2240

> Dorenbosch M, Verweij MC, Nagelkerken I, Jiddawi N, van der Velde G (2004a) Homing and daytime tidal movements of juvenile snappers (Lutjanidae) between shallowwater nursery habitats in Zanzibar, western Indian Ocean. Environ Biol Fishes 70:203-209

Dorenbosch M, van Riel MC, Nagelkerken I, van der Velde G 
(2004b) The relationship of reef fish densities to the proximity of mangrove and seagrass nurseries. Estuar Coast Shelf Sci 60:37-48

> Dorenbosch M, Grol MGG, Nagelkerken I, van der Velde G (2005a) Distribution of coral reef fishes along a coral reefseagrass gradient: edge effects and habitat segregation. Mar Ecol Prog Ser 299:277-288

- Dorenbosch M, Grol MGG, Christianen MJA, Nagelkerken I, van der Velde G (2005b) Indo-Pacific seagrass beds and mangroves contribute to fish density and diversity on adjacent coral reefs. Mar Ecol Prog Ser 302:63-76

> Dorenbosch M, Verberk WCEP, Nagelkerken I, van der Velde G (2007) Influence of habitat configuration on connectivity between fish assemblages of Caribbean seagrass beds, mangroves and coral reefs. Mar Ecol Prog Ser 334: 103-116

Duarte CM, Kirkman H (2001) Methods for the measurement of seagrass abundance and depth distribution. In: Short FT, Coles RG (eds) Global seagrass research methods. Elsevier, Amsterdam, p 141-153

Edgar GJ (1992) Patterns of colonization of mobile epifauna in a Western Australian seagrass bed. J Exp Mar Biol Ecol 157:225-246

Edgar GJ, Shaw C (1995) The production and trophic ecology of shallow-water fish assemblages in southern Australia I. Species richness, size-structure and production of fishes in Western Port, Victoria. J Exp Mar Biol Ecol 194:53-81

Fonseca MS, Kenworthy WJ (1987) Effects of current on photosynthesis and distribution of seagrasses. Aquat Bot 27:59-78

Froese R, Pauly D (eds) (2005) FishBase. www.fishbase.org

> Gambi MC, Nowell ARM, Jumars PA (1990) Flume observations on flow dynamics in Zostera marina (eelgrass) beds. Mar Ecol Prog Ser 61:159-169

Gell FR, Whittington MW (2002) Diversity of fishes in seagrass beds in the Quirimba Archipelago, northern Mozambique. Mar Freshw Res 53:115-121

Gillanders BM, Able KW, Brown JA, Eggleston DB, Sheridan PF (2003) Evidence of connectivity between juvenile and adult habitats for mobile marine fauna: an important component of nurseries. Mar Ecol Prog Ser 247:281-295

Grober-Dunsmore R, Frazer TK, Lindberg WJ, Beets J (2007) Reef fish and habitat relationships in a Caribbean seascape: the importance of reef context. Coral Reefs 26: 201-216

Gullström M, de la Torre-Castro M, Bandeira SO, Björk M and others (2002) Seagrass ecosystems in the Western Indian Ocean. Ambio 31:588-596

Gullström M, Lundén B, Bodin M, Kangwe JW, Öhman MC, Mtolera MSP, Björk M (2006) Assessment of changes in the seagrass-dominated submerged vegetation of tropical Chwaka Bay (Zanzibar) using satellite remote sensing. Estuar Coast Shelf Sci 67:399-408

Heck KL Jr, Orth RJ (1980) Seagrass habitats: the roles of habitat complexity, competition and predation in structuring associated fish and motile macro-invertebrate assemblages. In: Kennedy VS (ed) Estuarine perspectives. Academic Press, New York, p 449-464

Heck KL Jr, Thoman TA (1984) The nursery role of seagrass meadows in the upper and lower reaches of the Chesapeake Bay. Estuaries 7:70-92

Heck KL Jr, Hays G, Orth RJ (2003) Critical evaluation of the nursery role hypothesis for seagrass meadows. Mar Ecol Prog Ser 253:123-136

Hemminga MA, Duarte CM (2000) Seagrass ecology. Cambridge University Press, Cambridge

Holm S (1979) A simple sequentially rejective multiple test procedure. Scand J Stat 6:65-70

Hovel KA, Fonseca MS, Myer L, Kenworthy WJ, Whitfield PE (2002) Effects of seagrass landscape structure, structural complexity and hydrodynamic regime on macrofaunal densities in North Carolina seagrass beds. Mar Ecol Prog Ser 243:11-24

Hyndes GA, Kendrick AJ, MacArthur LD, Stewart E (2003) Differences in the species- and size-composition of fish assemblages in three distinct seagrass habitats with differing plant and meadow structure. Mar Biol 142:1195-1206

Jackson EL, Rowden AA, Attrill MJ, Bossey SJ, Jones MB (2001) The importance of seagrass beds as a habitat for fishery species. Oceanogr Mar Biol Annu Rev 39:269-303

> Jelbart JE, Ross PM, Connolly RM (2007) Fish assemblages in seagrass beds are influenced by the proximity of mangrove forests. Mar Biol 150:993-1002

Jenkins GP, Wheatley MJ (1998) The influence of habitat structure on nearshore fish assemblages in a southern Australian embayment: comparison of shallow seagrass, reef-algal and unvegetated sand habitats, with emphasis on their importance to recruitment. J Exp Mar Biol Ecol 221:147-172

> Kirsch KD, Valentine JF, Heck KL Jr (2002) Parrotfish grazing on turtlegrass Thalassia testudinum: evidence for the importance of seagrass consumption in food web dynamics of the Florida Keys National Marine Sanctuary. Mar Ecol Prog Ser 227:71-85

Liedloff A (1999) Mantel nonparametric test calculator version 2.0 (Shareware version). CSIRO sustainable ecosystems. Tropical Ecosystems Research Centre, Winnellie, NT

> Livingston RJ (1984) The relationship of physical factors and biological response in coastal seagrass meadows. Estuaries 7:377-390

Lugendo BR, Pronker A, Cornelissen I, de Groene A and others (2005) Habitat utilisation by juveniles of commercially important fish species in a marine embayment in Zanzibar, Tanzania. Aquat Living Resour 18:149-158

> Mantel N (1967) The detection of disease clustering and a generalized regression approach. Cancer Res 27:209-220

> McClanahan TR (1988) Seasonality in East Africa's coastal waters. Mar Ecol Prog Ser 44:191-199

- McClanahan TR, Mangi S (2000) Spillover of exploitable fishes from a marine park and its effect on the adjacent fishery. Ecol Appl 10:1792-1805

Mohammed SM (1998) Nutrient dynamics and exchanges between a mangrove forest and a coastal embayment: Chwaka Bay, Zanzibar. PhD thesis, Stockholm University

Morin PJ (1999) Community ecology. Blackwell Science, Malden, MA

Mumby PJ, Edwards AJ, Arias-González JE, Lindeman KC and others (2004) Mangroves enhance the biomass of coral reef fish communities in the Caribbean. Nature 427 : 533-536

> Nagelkerken I, van der Velde G (2002) Do non-estuarine mangroves harbour higher densities of juvenile fish than adjacent shallow-water and coral reef habitats in Curaçao (Netherlands Antilles)? Mar Ecol Prog Ser 245:191-204

Nagelkerken I, van der Velde G, Gorissen MW, Meijer GJ, van't Hof T, den Hartog C (2000) Importance of mangroves, seagrass beds and the shallow coral reef as a nursery for important coral reef fishes, using a visual census technique. Estuar Coast Shelf Sci 51:31-44

> Nagelkerken I, Kleijnen S, Klop T, van den Brand RACJ, Cocheret de la Morinière $E$, van der Velde G (2001) Dependence of Caribbean reef fishes on mangroves and seagrass beds as nursery habitats: a comparison of fish 
faunas between bays with and without mangroves/seagrass beds. Mar Ecol Prog Ser 214:225-235

Nakamura Y, Sano M (2004) Comparison between community structures of fishes in Enhalus acoroides- and Thalassia hemprichii-dominated seagrass beds on fringing coral reefs in the Ryukyu Islands, Japan. Ichthyol Res 51:38-45

Orth RJ, Heck KL Jr, van Montfrans J (1984) Faunal communities in seagrass beds: a review of the influence of plant structure and prey characteristics on predator-prey relationships. Estuaries 7:339-350

Parrish JD (1989) Fish communities of interacting shallowwater habitats in tropical oceanic regions. Mar Ecol Prog Ser 58:143-160

Pollard DA (1984) A review of ecological studies on seagrassfish communities, with particular reference to recent studies in Australia. Aquat Bot 18:3-42

Robblee MB, Zieman JC (1984) Diel variation in the fish fauna of a tropical seagrass feeding ground. Bull Mar Sci 34: $335-345$

Russell BD, Gillanders BM, Connolly RM (2005) Proximity and size of neighbouring habitat affects invertebrate diversity. Mar Ecol Prog Ser 296:31-38

Shulman MJ (1985) Recruitment of coral reef fishes: effects of distribution of predators and shelter. Ecology 66: 1056-1066

Sirota L, Hovel KA (2006) Simulated eelgrass Zostera marina structural complexity: effects of shoot length, shoot density, and surface area on the epifaunal community of San Diego Bay, California, USA. Mar Ecol Prog Ser 326: 115-131

Smith MM, Heemstra PC (1991) Smith's sea fishes. Southern Book Publishers, Johannesburg

Editorial responsibility: Kenneth Heck Jr., Dauphin Island, Alabama, USA
Smouse PE, Long JC, Sokal RR (1986) Multiple regression and correlation extensions of the Mantel test of matrix correspondence. Syst Zool 35:627-632

> Sogard SM, Powell GVN, Holmquist JG (1987) Epibenthic fish communities on Florida Bay banks: relations with physical parameters and seagrass cover. Mar Ecol Prog Ser 40:25-39

Tanner JE (2003) Patch shape and orientation influences on seagrass epifauna are mediated by dispersal abilities. Oikos 100:517-524

Tanner JE (2006) Landscape ecology of interactions between seagrass and mobile epifauna: the matrix matters. Estuar Coast Shelf Sci 68:404-412

Tobisson E, Andersson J, Ngazi Z, Rydberg L, Cederlöf U (1998) Tides, monsoons and seabed: local knowledge and practice in Chwaka Bay, Zanzibar. Ambio 27:677-685

Underwood AJ (1981) Techniques of analysis of variance in experimental marine biology and ecology. Oceanogr Mar Biol Annu Rev 19:513-605

> Valentine JF, Heck KL Jr, Blackmon D, Goecker ME and others (2007) Food web interactions along seagrass-coral reef boundaries: effects of piscivore reductions on crosshabitat energy exchange. Mar Ecol Prog Ser 333:37-50

Weinstein WP, Heck KL Jr (1979) Ichthyofauna of seagrass meadows along the Caribbean coast of Panama and in the Gulf of Mexico: composition, structure and community ecology. Mar Biol 50:97-107

Worthington DG, Ferrell DJ, McNeill SE, Bell JD (1992) Effects of the shoot density of seagrass on fish and decapods: Are correlations evident over larger spatial scales? Mar Biol 112:139-146

Submitted: January 2, 2006; Accepted: January 25, 2008 Proofs received from author(s): June 23, 2008 